\title{
Influence integrated science model and implamantation learning with the unity of science in basic biology course to increase critical thinking
}

\author{
Nur Khasanah, Sajidan, Sutarno, Baskoro \\ Biology Education Department of Post Graduate Program Sebelas Maret University, \\ J1. Ir. Sutami 36A Kentingan Jebres Surakarta 57126, INDONESIA \\ E-mail: nurkhasanah@walisongo.ac.id
}

\begin{abstract}
This research purposed to investigate the effect of integrated science model and its implementation in learning by Unity of Science in Basic Biology courses to improve students' critical thinking. This method research is a quasiexperimental with experimental design posttest only control group design. The population was all students of the first semester Biology, 2015/2016 academic year with consists of two classes. Samples were taken with a simple random sampling technique. The data was collected using an open essay tests and observation of critical thinking skills. Data were analyzed with descriptive analysis and MANOVA test. The results showed as follows: (1) There are differences between the understanding of basic biology concepts students learn to use the integrated science model of with students who learn to use the direct teaching model $(\mathrm{F}=$ $7.783 ; \mathrm{p}<0.05),(2)$ there are differences in thinking skills critical significantly between students learning with integrated science model and its implementation in Unity of science learning with students who learn to use the direct teaching model $(\mathrm{F}=11.11, \mathrm{p}<0.05)$.
\end{abstract}

\section{Introduction}

Education in Colleges, internal challenges faced by the College of Islamic Religion (PTAI) and Public Higher Education (PTU), among others, the fulfillment of the National Education Standards in Higher Education (SNPT). Some of the obstacles of which is a standard process that has not been as expected, for the standard process necessary to get attention by doing development. Development can be carried out by an educator is to develop a learning model for students as prospective teachers (Silvi, 2013).

Basic biology concepts for new students is needed in starting lectures in Biology Education. Basic biology provide supplies students in learning the concepts of biology at the level of the next lecture. Basic biology is the science of searching for answers to the question of what, why, and how living things and their characteristics. Natural phenomena pertaining to the composition, structure and properties, living beings. Learners biology which is part of the science lesson not only to master certain amount of knowledge, but also must provide adequate space for the growing development of a scientific attitude, to practice problem-solving process, and their application in real life (Dracup, 2012). 
At this time biology learning not yet expectations. Still there is a common biology value of the analysis of the results of asassment in 2014 and 2015 of the semester students shows that more than $65 \%$ only able to reach the middle level, almost $25 \%$ is still low and only $10 \%$ were at the level above. In connection with the foregoing, the low quality of teaching basic biology demanded how to be better. This is likely due to less attention in terms of the learning process. Learning is more oriented to a final exam led to the learning that takes just a transfer of information to students. As a result, students in learning character only memorize concepts, theories have been there, so it failed to give an understanding to the students the concepts learned to be applied in everyday life.

Integrated science is one of the models for the implementation of the curriculum is recommended to be applied at all levels of education (Mas'ud, 2001; Kemendikbud, 2013). Integrated science is important, so every student gets the opportunity to examine a variety of ways that would be more meaningful and critical thinking. Integration science model in a break through to participate in the implementation of the curriculum in 2013 at the College in accordance with government policy. Through the integrated model of science students can gain direct experience, thus increasing the power to receive, store, and apply the concepts they have learned. Thus, students are trained to be able to find themselves a variety of concepts studied thoroughly (holistic), meaningful, and critical thinking.

Implementation model of learning in the classroom by implementing the integration of science and religion is a necessity and to equip (Bagir, 2005). Unity of Sciences (wahdat al 'ulum) is a form of integration of science and Islamic values (Muhyar, 2012). The relationship between faith and science is whether the direct knowledge or belief beliefs cause knowledge ?. It turns out there is a relationship between beliefs, knowledge and practices related to each other (Mansour, 2008, 2009)

\section{Method}

The population in this study were students of Biology Education class UIN Walisongo Semarang in 2014/2015 2013/2014 63 people consisting of 2 classes. This study is the population, meaning that all of the population to be sampled in the study (Arikunto, 2005). Then, set the class (30 people) as an experimental class and one class (35) as the control class with random techniques. Integrated science learning model as independent variable in the study for an experimental class and teaching models directly to the control class. Both models in the implementation with unity of science in the classroom. While the dependent variable is the common understanding of biology concepts and critical thinking skills of students.

The research instruments consisted of the learning device (RPS and evaluation instruments) and data collection instruments (tests understanding of the concept and student observation sheet). Learning tools used in the implementation of learning, while the data collection instruments as research data retrieval tool. The research data covers the value of understanding the concept of which was collected by the testing techniques esay written in the form of an open and critical thinking skills obtained from 
observations made in class. Prior to use, all such instruments to test the validity. RPS and the observation sheet for students to test the validity skilled in the art (judgment experts).

Of the 50 test items are valid understanding of the concept of 35 points while the instrument observation of students' critical thinking skills are valid 30 items of 35 items tested for validity. Then field tested against the 35 points test understanding of concepts and a 30 item questionnaire critical thinking skills. This research data of value common understanding of biology concepts and values students' critical thinking skills. The data were analyzed with descriptive statistics and MANOVA test. Descriptive analysis is used to describe the value of understanding the concept of basic biology and critical thinking skills of each model of learning. While MANOVA test for the testing of hypotheses that have been formulated at a significance level of $5 \%$.

Before the MANOVA test, test prerequisites, namely: normality test, and homogeneity of variance. Normally distributed data, homogeneous variances, and correlations between variables is smaller than 0,800 , the MANOVA test can be done. The hypothesis of this study, namely: (1) there are differences in understanding of the concept of Biology common and critical thinking skills among students who study uses a model Integrated science that implementation of the unity of science with which students learn to use the model of direct teaching, (2) there are differences in critical thinking skills among the students who use the Integrated model of science that implementation with the unity of science with students who use direct teaching model.

The first hypothesis was tested with SPSS Program is 16. The second hypothesis is based on the Test of Between-Subject Effects in SPSS output. If the research hypothesis is accepted, then followed with LSD test to determine the significance of differences in the average value of the dependent variable of this study.

\section{Results and Discussion}

Description of the concept of basic biology and critical thinking skills of each student learning models, descriptive can be presented in Table 1

Table 1. Data biology concept and Critical thinking skills

\begin{tabular}{cllccccccc}
\hline \multirow{2}{*}{ No } & \multirow{2}{*}{ Variable } & \multicolumn{3}{c}{ Integrated science } & \multicolumn{5}{c}{ Direct learning } \\
\cline { 2 - 9 } & Mean & Median & Modus & SD & Mean & Median & Modus & SD \\
\hline 1 & $\begin{array}{l}\text { Known } \\
\text { biology } \\
\text { concept }\end{array}$ & 67,13 & 66 & 64 & 11,213 & 61,66 & 65 & 58 & 11,24 \\
2 & $\begin{array}{l}\text { Critical } \\
\text { thinking skills }\end{array}$ & 77,78 & 79 & 80 & 67,75 & 75,81 & 75 & 76 & 6,41 \\
\hline
\end{tabular}

Table 1, the achievement of the average value of a common understanding of the concept of Biology and critical thinking skills of students who use the Integrated model of science is higher than the students learn to use the direct teaching model. If categorized by PAP five-point scale, the average value of understanding the concept of 
Biology common and critical thinking skills of students on the model of Integrated science category qualifier "medium", while the average value of understanding the concept of basic biology on the model of direct teaching is also on the qualification "moderate".

Classification of critical thinking skills qualification refers to the classification scale PAN five. Based on this classification, the average value of critical thinking skills in science Integrated models currently on the qualification of "good", while the average value of critical thinking skills in the direct teaching models also qualified "moderate".

Descriptive average value of critical thinking skills in science Integrated models was higher than the average value of the direct teaching model. Average achievement of critical thinking skills in each of these aspects as shown in Table 2.

Table 2. Differences critical thinking skills

\begin{tabular}{llll}
\hline \multirow{2}{*}{ No } & Critical thinking & Mean & \\
\cline { 3 - 4 } & skills & Integrated science & Direct learning \\
\hline 1 & Questions & 80,5 & 77,5 \\
2 & Discussion & 78,5 & 70 \\
3 & argumentation & 85.5 & 75,5 \\
\hline
\end{tabular}

Table 2, the achievement of the average value for each dimension of critical thinking skills on a model of integrated science is higher than the average value of the direct teaching model. The average value of understanding the concept of the integrated model of translational science to dimensions that are in the qualification of "good", while for the dimensions of interpretation and extrapolation qualified "moderate".

\section{Discussion}

Based on the results of data analysis, that there is influence Integrated model of science that implementation with the Unity of Science towards a common understanding of biology concepts and critical thinking skills of students. From the analysis of hypothesis testing First, there are differences in understanding of the basic biology student concept between students who follow the model of Integrated science that implementation with the Unity of Science to students who follow the model of direct teaching. This is because the stages of the implementation model of science Integrated with Unity of Science can develop a scientific attitude and understanding of the concept of basic biology and critical thinking.

With the process of induction of specific things that are found in the learning process towards the common things that the conclusion, there will be a process of knowledge construction of students who briefed the concept of enabling understanding of the concept of student self.

Second hypothesis test is found, that there are differences significantly critical thinking skills among students who follow the model of Integrated science that implementation with the unity of science with hands-on teaching models. On the Integrated science model, curiosity emerged in the implementation of Integrated science 
teaching model. The question that arises show students' curiosity to know the results of the scientific process that has been done. Objective attitude to data on the Integrated science model looks on. Students are required to record data or information discussion and question and answer obtained from the experiments to find the concepts expected, so from this activity will form an honest and objective attitude. The attitude of willingness to believe can be grown in the Integrated science model when in group discussions. At the presentation of experiments of the students produce findings and specific data which may differ from the views of students.

The results of discussions generate new information and implementation in their life in society. Integrated science model give students the opportunity for the formation of critical thinking attitude (Facione, 2011). The critical thinking skills of students arising from some of the questions and answers while and opinions that arise and are connected with the meaning of reference. The critical thinking skills also arise because of the variety of opinions, ideas, feedback or criticism that occurs during the discussion and interpretation of the Quran and its implementation in everyday life (Tsai, 2002). Critical thinking skills is also against the findings generated from experiments in learning. Critical thinking skills like this are rare in the direct teaching model.

Instead of direct teaching models more emphasis on the delivery of content verbally process of existing concepts. Direct teaching model is the dominant role of teachers and students lack required to find concepts that exist. This makes the knowledge of students is less developed and less meaningful. Less meaningless learning lead to less formation of a scientific attitude and critical learners (Facione, 2011; Vargil, 2012). Less direct teaching models accommodate the understanding of translation, since this model is less demanding their active student activities. Students character only accept concepts submitted by teachers so that the answer is more inclined to be reiterated that there is.

Through direct teaching model understanding still low, because this model does not look any learning activity that directs the student in the opinion to express ideas to be interpreted more as a conclusion. Students to explain the meaning of the information, because the teaching model of direct provision of training students to elaborate on their knowledge through the tasks given. Learning only limited transfer information to students without any understanding of the information. The thing is not so basics enough knowledge to students, resulting in the student's knowledge limited to the rote and students will be less able to make predictions of phenomena that exist (Vargil, 2012).

\section{Conclusion}

The study produced findings that the science of integrated learning model implemented by the unity of science affect the basic understanding of biology concepts and critical thinking skills of students. In more detail can be described as follows: (1) there are differences in the average value of understanding the concept of basic biology and critical thinking skills of students, which significantly between groups of students studying the model of Integrated science that implementation of the unity of sciences with a group of students studying with direct teaching model, (2) there are differences in 
the average value of the scientific attitude significantly between groups of students studying with Integrated science that implementation with the unity of sciences with a group of students who learn by direct teaching model. Based on the findings in this study, can be proposed some suggestions: (1) Integrated model of science that implementation with the unity of sciences can be used as a model of learning in the classroom, especially in teaching basic biology, (2) the application of the Integrated model of science, should be done with earnest and according to the procedure as well as the preparation of faculty and students to obtain optimal results.

\section{References}

[1] Abdurrahman Mas'ud (2001) Menggagas Format Pendidikan Nondikotomik (Humanisme Religius Sebagai Paradigma Pendidikan Islam), Yogyakarta: GAMA MEDIA

[2] Arsyad, Azhar dkk. (2009). Membangun Universitas menuju Peradaban Islam Modern. Makassar: Alauddin Press

[3] Atilla Cimer, et al. (2015). Crtitical Thinking Level of Biologu Classroom survey: Ctlobics. The Online Journal of New Horizons in Education Vol 3. www.tojned.net

[4] Bagir, Zainal Abidin, et al (2005), Integrasi Ilmu dan Agama Interpretasi dan Aksi, Mizan, Bandung: Mizan

[5] Dracup Mary (2012). Designing online role plays with a focus on story development to support engagement and critical learning for higher education students. Journal of Learning Design Vol.5

[6] Facione Peter A (2011), Critical Thinking: What It Is and Why It Counts, Measured Reasons and The California Academic Press, Millbrae, CA

[7] Mansour N (2008), The Experiences and Personal Religious Beliefs of Egyptian Science Teachers as a Framework for Understanding the Shaping and Reshaping of their Beliefs and Practices about Science-Technology-Society (STS). International Journal of Science Education. Vol. 30, No. 12, 5 October 2008, pp. 1605-1634

[8] Muhyar (2012), Integrasi Sains dan Agama (Strategi Konvensi IAIN Walisongo Menjadi UIN Walisongo), Semarang: Seminar Nasional

[9] Robert. E. Slavin, Penerjemah Marianto Samosir (2011). Psikologi Pendidikan: Teori dan Praktik, Edisi Ke-9, Jakarta, PT. Indeks

[10] Silvi (2013), Pendekatan Ilmiah dalam Pembelajaran-Bahan Pelatihan Nasional. Hotel Siliwangi 18 September 2013

[11] Shirly A Vargil. Orit Herscovitz (2012) Yeduhit Judy Dori. Teaching Thinking Skills in Context-Based Learning: Teachers' Challenges and Assessment Knowledge. J Sci Educ Technol, vol 21:207-225

[12] Tsai, C. (2002). Nested epistemologies: science teachers' beliefs of teaching, learning and science. International Journal of Science Education, 24(8), 771783. 